SC-R-66-871

April 1966 ,

\title{
Reprint
}

corf $-660319-2$

\section{SURFACE PLATE GAGING}

E. S. Roth

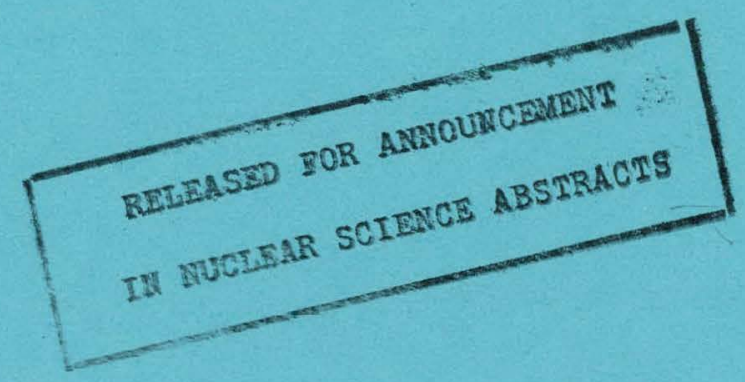




\section{DISCLAIMER}

This report was prepared as an account of work sponsored by an agency of the United States Government. Neither the United States Government nor any agency Thereof, nor any of their employees, makes any warranty, express or implied, or assumes any legal liability or responsibility for the accuracy, completeness, or usefulness of any information, apparatus, product, or process disclosed, or represents that its use would not infringe privately owned rights. Reference herein to any specific commercial product, process, or service by trade name, trademark, manufacturer, or otherwise does not necessarily constitute or imply its endorsement, recommendation, or favoring by the United States Government or any agency thereof. The views and opinions of authors expressed herein do not necessarily state or reflect those of the United States Government or any agency thereof. 


\section{DISCLAIMER}

Portions of this document may be illegible in electronic image products. Images are produced from the best available original document. 
Presented at: WESTEC CONVENTION, Paper IQ66-704, March $7-11,05,1966$

Los Angeles, California.

\section{Published by: American Society of Tool and Manufacturing Engineers, 20601 Ford Road, Dearborn, Michigan 48128}

Issued by Sandia Corporation,

a prime contractor to the

United States Atomic Energy Commission

\section{LEGAL NOTICE}

This report was prepared as an account of Government sponsored work. Neither the United States, nor the Commission, nor any person acting on behalf of the Commission:

A. Makes any warranty or representation, expressed or implied, with respect to the accuracy, completeness, or usefulness of the information contained in this report, or that the use of any information, apparatus, method, or process disclosed in this report may not infringe privately owned rights; or

B. Assumes any liabilities with respect to the use of, or for damages resulting from the use of any information, apparatus, method, or process disclosed in this report.

As used in the above, "person acting on behalf of the Commisston" includes any employee or contractor of the Commission, or employee of such contractor, to the extent that such employee or contractor of the Commission or employee of such contractor prepares, disseminates, or provides access to, any information pursuant to his employment or contract with the Commission, or his employment with such contractor. 


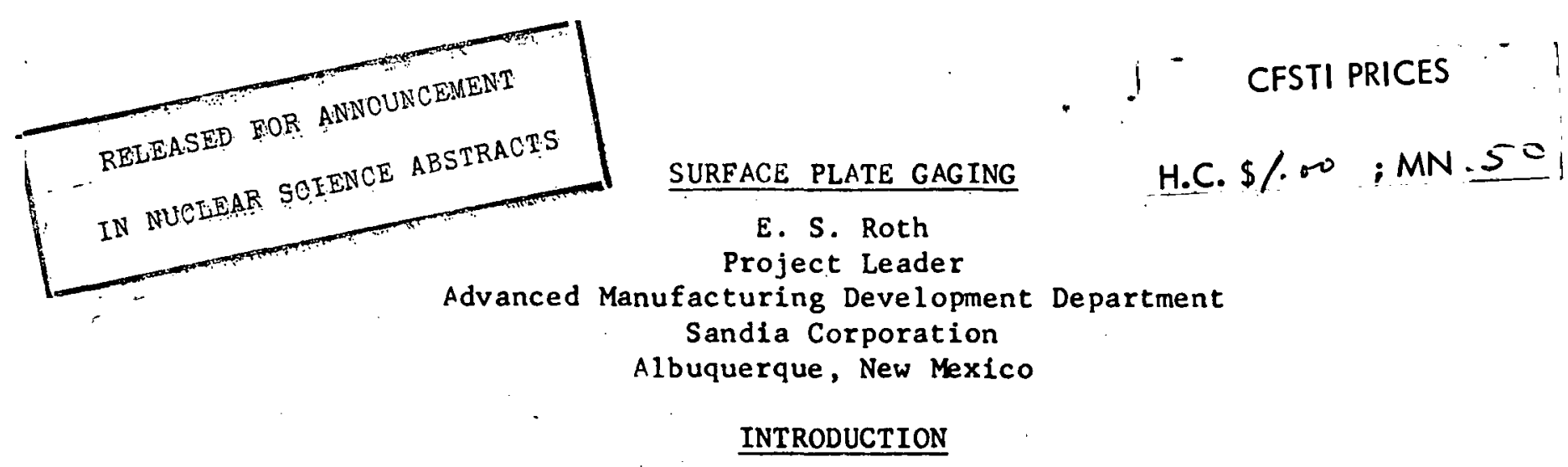

Surface plate inspectors can approximate a number of functional gages using standard fixtures. This approach fits nicely into situations where a lot (batch) of similar parts do not all require variables inspection data. These go or not-go surface plate gages will be as accurate as the care and,planning taken by the inspector in their setup.

The surface plate gage setups illustrated are compatible with the Mil-Std-8C and ASA Y14.5 dimensioning and tolerancing standards when the MMC (Maximum Material Condition) callouts are specified. They are especially useful methods of evaluating initial production parts when functional gages are not yet available, and can be constructed to reflect wear and gage tolerances, if desired.

\section{SURFACE PLATE GAGE SETUPS}

Figure 1 shows a pin that must be straight within .002 inch total indicator reading when it is at MMC (.400 inch in dia.) and can deviate to a straightness of .004 inch total indicator reading when .398 inch in dia. Instead of measuring each pin to its exact dia., and then computing the exact straightness tolerance required, ( $1 . e$. , a .3992 dia. pin is allowed a .0028 inch total indicator reading), the inspector can more rapidly inspect a series of these parts with the setup shown in Figure 2 .

The surface plate gage in Figure 2 has a .402 (.400 MMC dia. plus .002 straightness at MMC) opening. The pin must merely roll under the "bridge" to be acceptable, providing it is no larger than .400 inch in dia., and smaller than .398 inch in dia.

Figure 3 shows a simple thickness requirement that is readily gaged with the two go and not-go gage stacks shown in Figure 4. These same methods could be used to check the pin limits in Figure 1 if other gages are not available.

Figure 5 shows a new method of locating a hole pattern on a part where the hole pattern location is not critical. Here the part designer is particularly interested in controlling the "break out" material between the hole and part periphery. The holes could be positionally toleranced and this figure will be referenced again when we discuss Figures 15 and 16 . Figure 6 shows a setup that will not accept an out of tolerance hole location for each of the four holes. The part periphery is placed on the gage block stack and the pin, which is clamped to the $V$ block, should not enter any hole when the part is relocated at each hole. The pin need only be somewhat smaller than the minimum hole size specified to be used.

Figure 7 illustrates a part with a variable perpendicularity tolerance. When the hole is finished to .505 inch in dia., the perpendicularity is .005 inch total indicator reading; when the hole is finished to .510 inch 
dia., the perpendicularity may increase to .010 inch total indicator reading. (All finished hole sizes in between have corresponding perpendicularity tolerances).

Figure 8 shows the functional setup gage consisting of a .500 dia. gage pin (.505 MMC hole size minus .005 inch perpendicularity tolerance allowed at $M M C$ ) clamped in a $V$ Block. If the part flts over the pin and datum surface $A$ contacts the $V$ Block - the part is acceptable providing the hole size is within the .505 to .510 inch dia. limits.

Figure 9 illustrates a difficult part to inspect using conventional means. The gage stack shown in Figure 10 is a true functional gage: (A discussion of the tolerance variables and slot to Datum Feature $B$ relationships might take up the major portion of this paper if discussed.) Suffice to say, the gage setup has a 2.000 inch distance between the outer gage blocks to accommodate Part Datum-Feature B at MC (2.000 inch on the finished part); a .500 inch wide slot gage (the slot is allowed no symmetry tolerance when it is $.500 \mathrm{Inch}$; and up to .010 symmetry tolerance when it is .510 inch wide) and the entire gage stack is placed on a surface plate which must contact $P$ art Datum Surface $A$ during gaging. If the part enters the gage, the inspector need only inspect the .510 inch max. slot width and 1.995 inch min. Datum B width to complete the inspection.

Figure 11 lllustrates another difficult to inspect part. To relleve the inspector of several calculations and individual setups depending on the actual size of Datum Feature $A$, the single functional gage setup shown in Figure 12 will suffice. The .600 inch dia. gage pin (.605 inch Mac hole minus the .005 inch dia. concentricity tolerance allowed at MC) and the .400 inch dia. pin (the MMC size of the datum hole) should be coaxial. If both pins enter and bottom in each hole, then all the inspector must do to complete the inspection is to check the .605 inch, .610 inch and .402 inch limits.

Figure 13 has omitted the series of basic coordinate contour locating dimensions for clarity and shows a contour tolerance of .010 total indicator reading normal to the basic contour. The inspection of such a requirement is time consuming (to say the least) using normal setup procedures. Figure 14 shows the go gage that can be set up consisting of standard surface plate equipment. The pin sizes are determined by drawing a greatly magnifled layout of the contour and then fitting magnified gage pins (a series of circles). to achieve a useful contour where the circles (pins) contact the go. (maximum) contour. (The layout: would be identical to Figure 14 except at a much larger scale.) This kind of gage can monitor production at a rapid rate.

Figure 15 shows a part containing a pattern of clearance holes located from part surfaces $B$ and $C$.. Each hole has a variable location and relation tolerance (.010 inch tolerance when .510 inch dia., .017 inch tolerance when .517 inch dia., etc.) that is allowed because of the MMC callout.

The setup gage, Figure 16, is complex and requires careful planning and could be held in place, as could the contour gage in Figure 14, by magnetic force instead of clamps if the part is non-magnetic. The pins (items 4) are all .500 inch in dia. (.510 inch hole at MMC minus .010 inch tolerance allowed at $M M C$ ) and their centers are .750 inch and 
1.750 inch basic from the angle plate and the parallel. The part holes should fit over the form gage pins and surfaces $B$ and $C$ should contact the angle plate and parallels for acceptance. The part primary datum surface should be able to be aligned parallel to the surface plate, which supports all these items in this plan view. The inspector must then check the .510 - .520 inch hole size $11 \mathrm{mits}$ to complete the inspection.

Not all of these setups are perfect (what is!) but they will speed up acceptance rates. I hope this paper w1ll encourage inspection organizations to develop additional gage setups that are specifically oriented towards their own products.

Referance: Punctional Gaging of Posttionally Toleranced Parts ASTME Manufacturing Data Series Book, 1964

This work was supported by the United States Atomic Energy Commission.

\section{LEGAL NOTICE}

This report was prepared as an account of Government sponsored work. Neither the United States,

A.

A. Makes any warrantert, or that the use racy, completeness, or use of any Information, appara

privately owned rights; or B. Assumes any liabslities with respect to the use or, or for dased this report.

use of any information, apparatus, method, or process disclosed in this eport. As used in the above, "person acting on behalf of the Commission" includes any employee or contractor of the Commission, or employee of such contractor, to the extent that such employee or contractor of the Commission, or employee of such contractor prepares, disseminates, or provides access to. any information pursuant to h/s employment or contract with the Commission, or his employment with such contractor. 


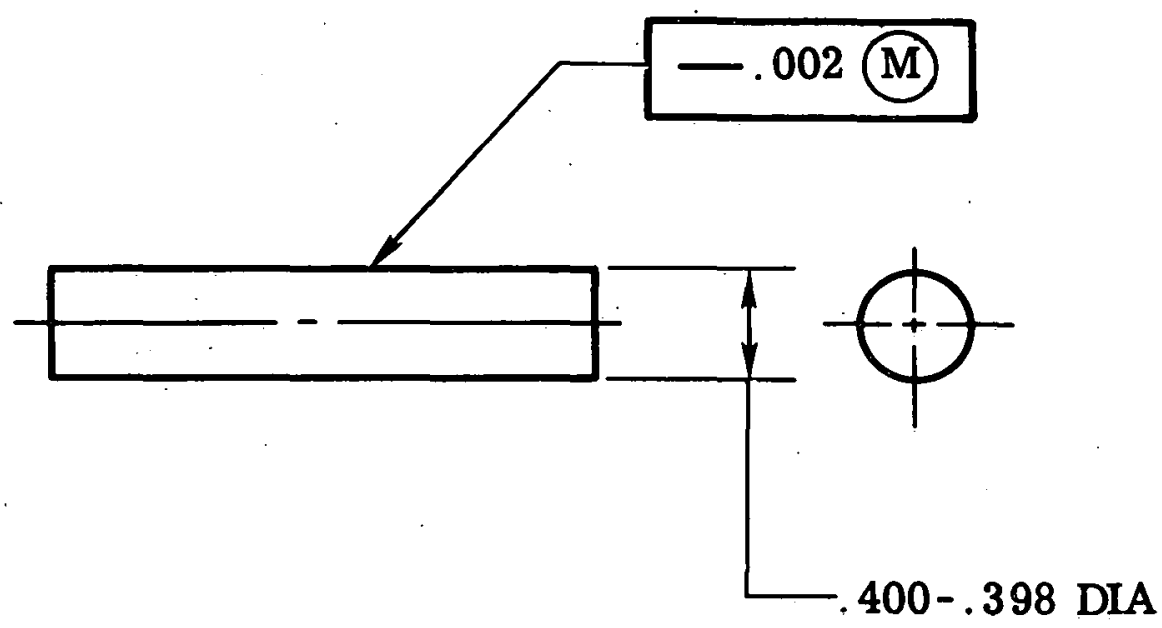

Figure 1 Part

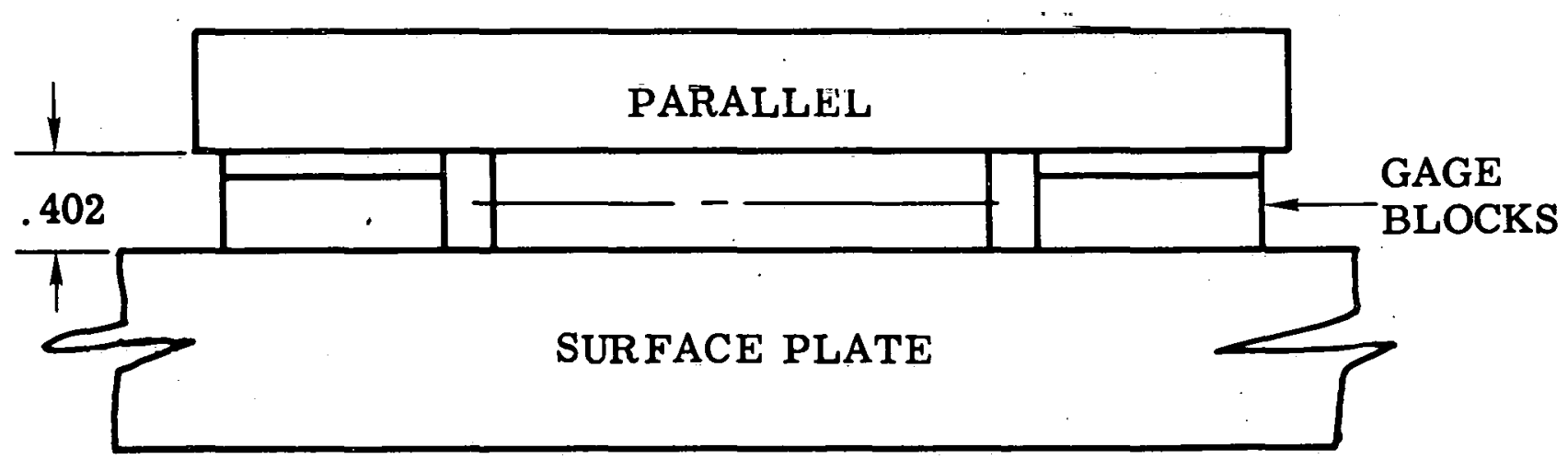

Figure 2 Gage Setup 

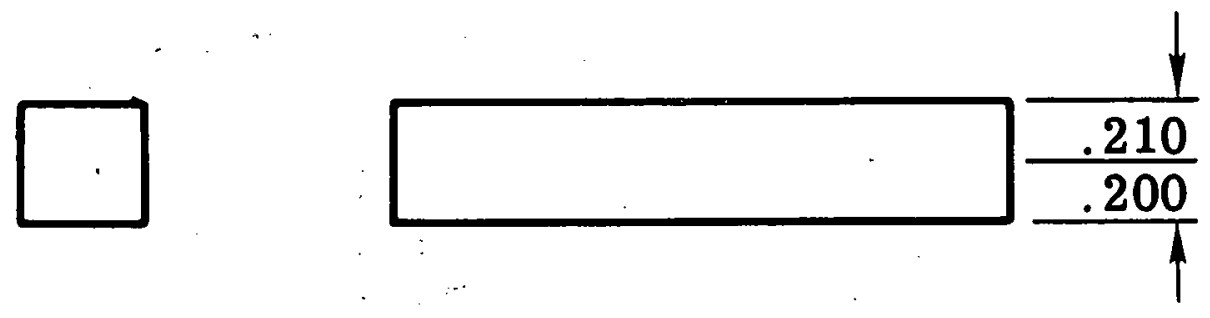

Figure 3 Part

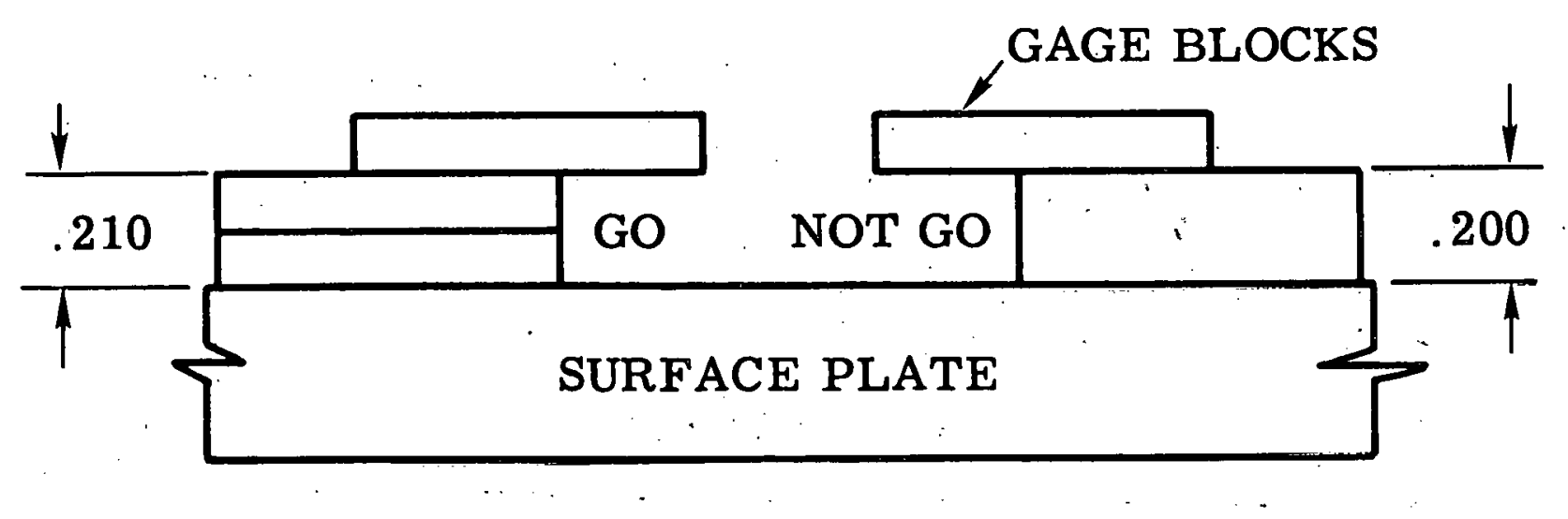

Figure 4 Gage Setup 


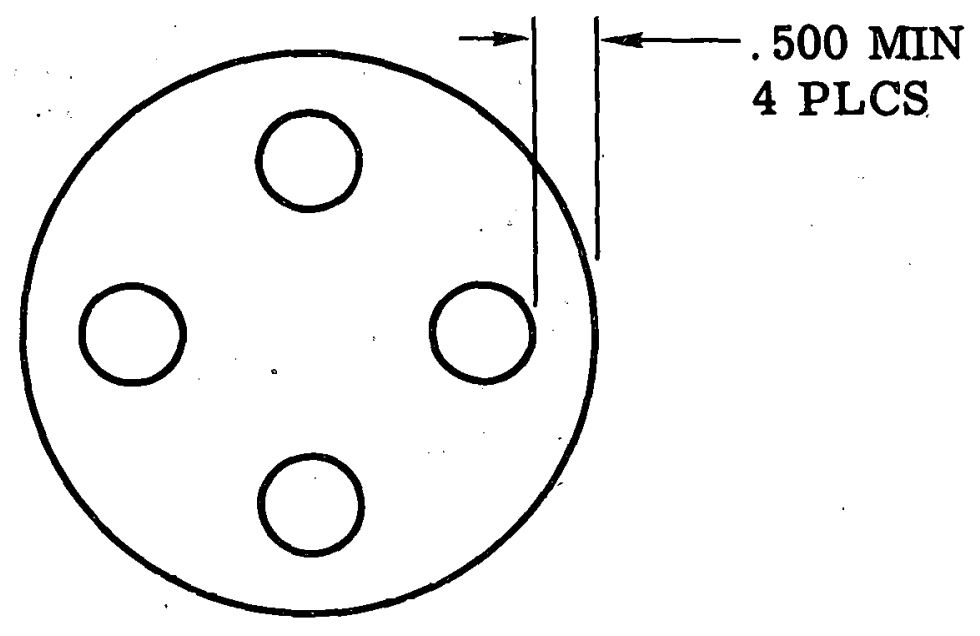

Figure 5 Part

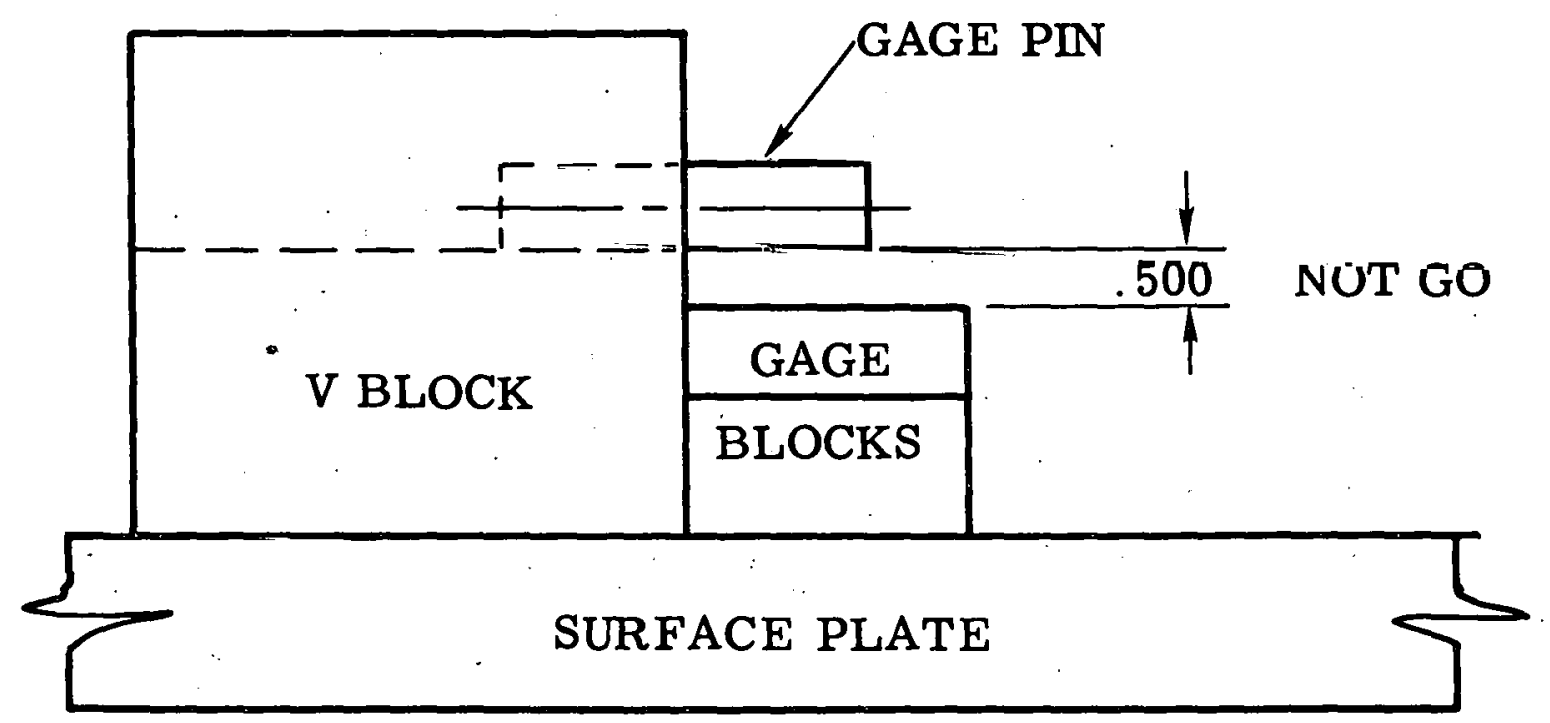

Figure 6 Gage Setup 


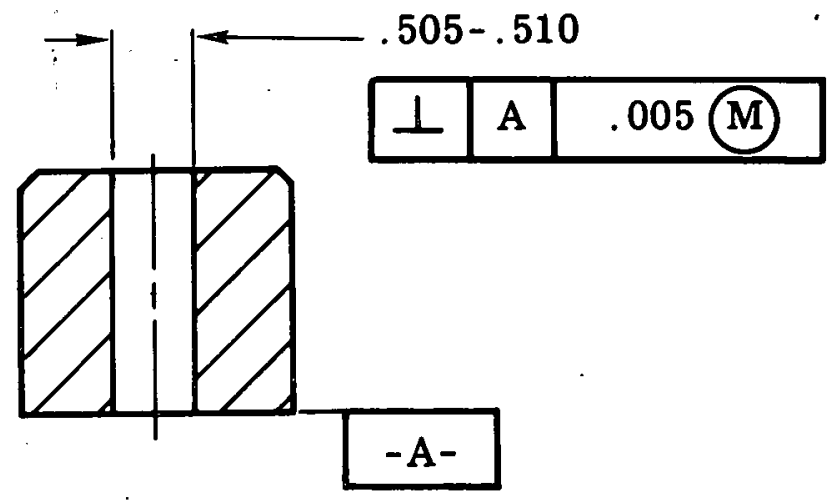

Figure 7 Part

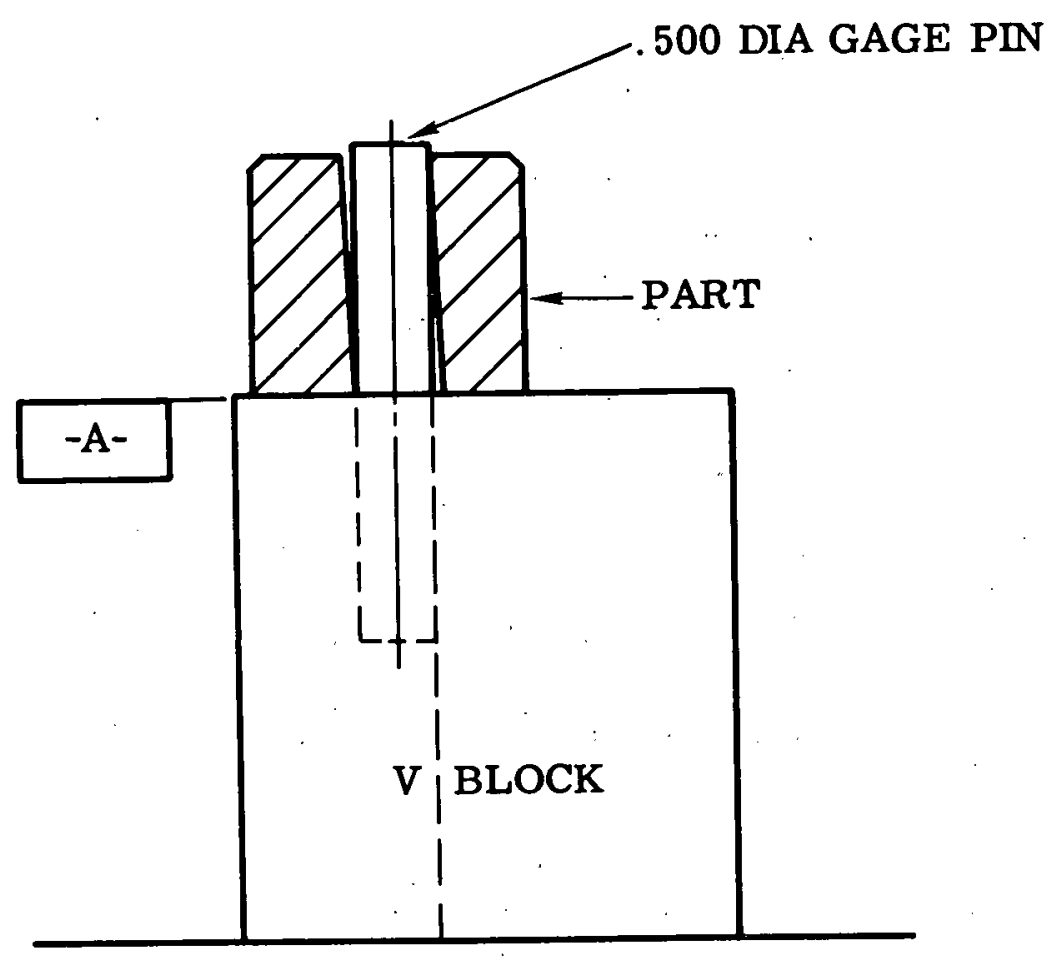

Figure 8 Gage Setup 


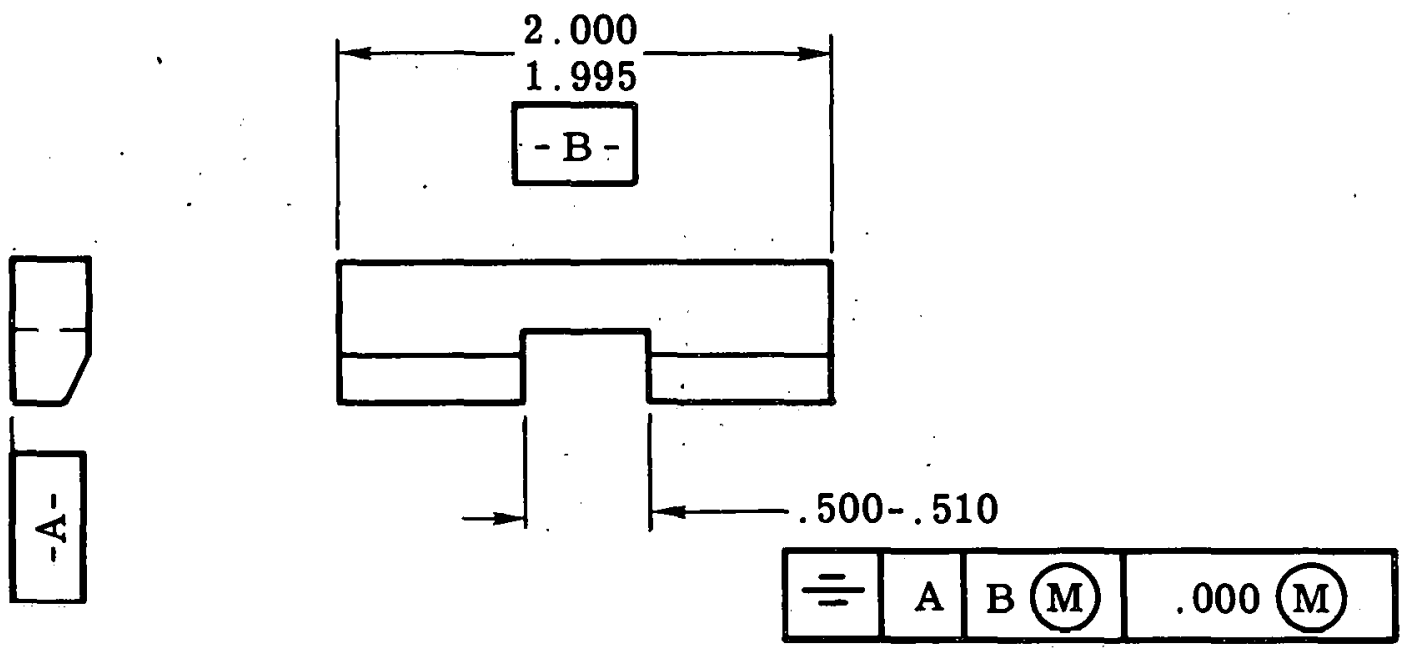

Figure 9 Part

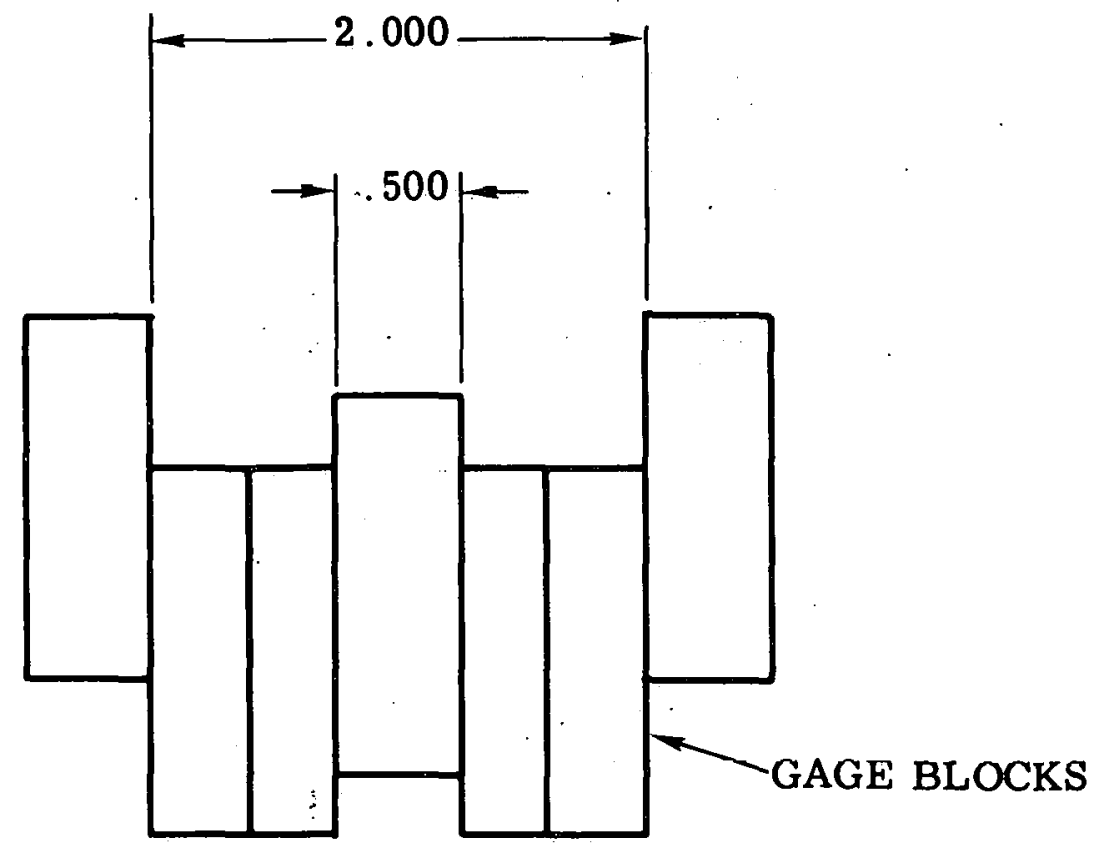

Figure 10 Gage Setup 


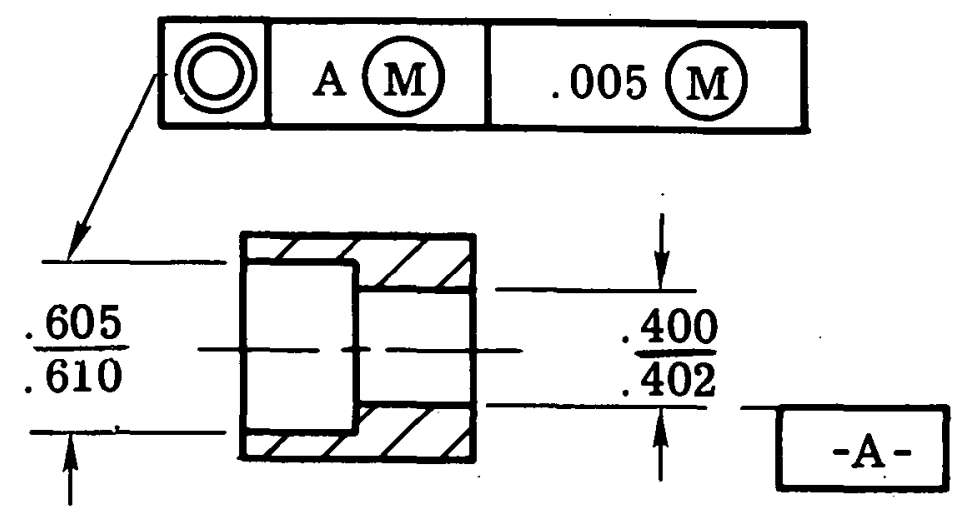

Figure 11 Part

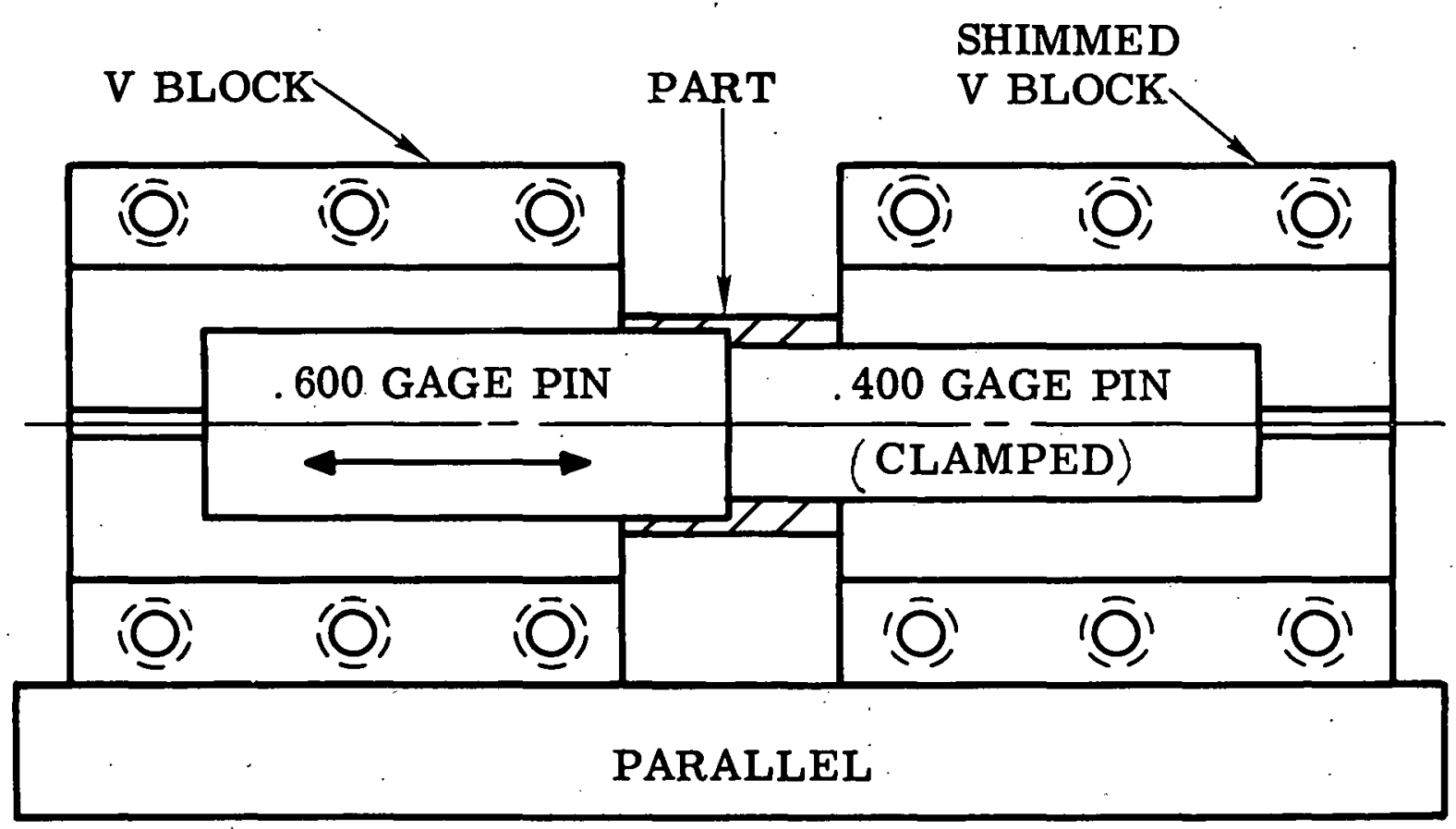

Figure 12 Gage Setup 


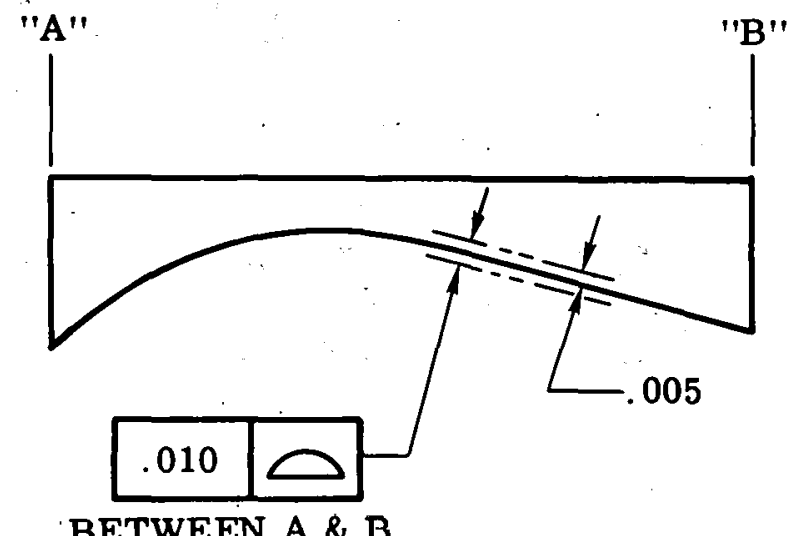

BETWEEN A \& B

Figure 13 Part

ITEM 1 = ANGLE PLATE

ITEM 2 = PARALLEL

ITEM 3 = GAGE BLOCK

ITEM 4 = GAGE PIN

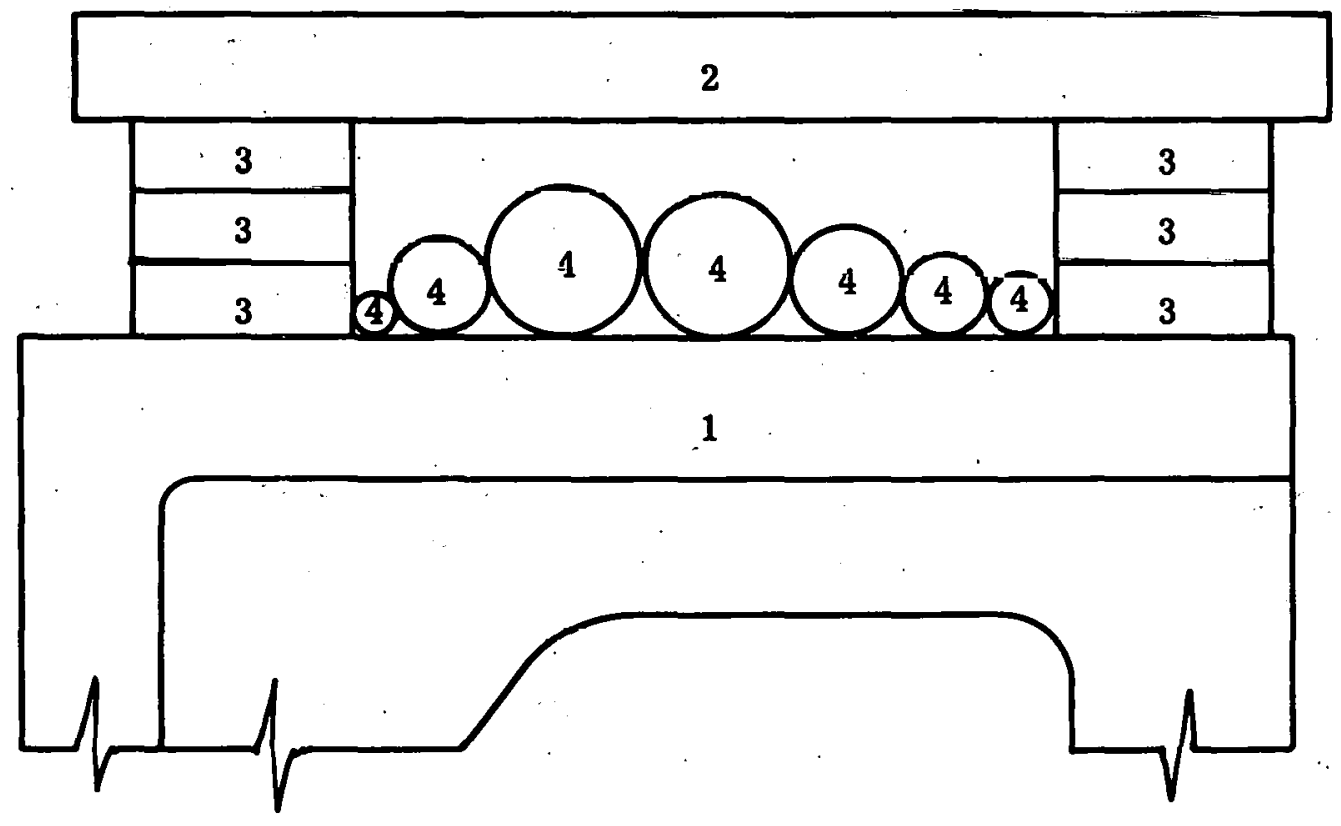

Figure 14 Gage Setup 


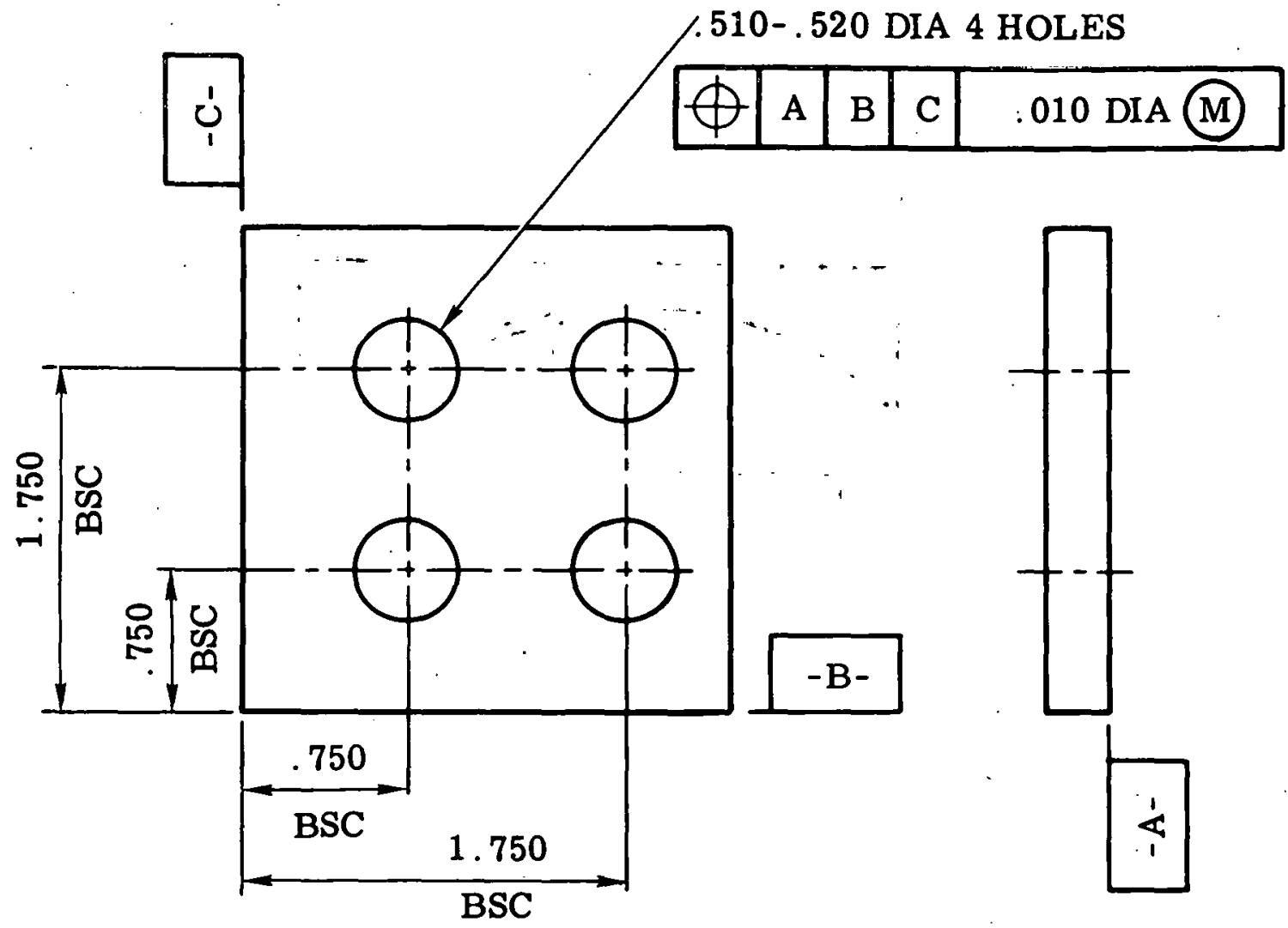

Figure 15 Part

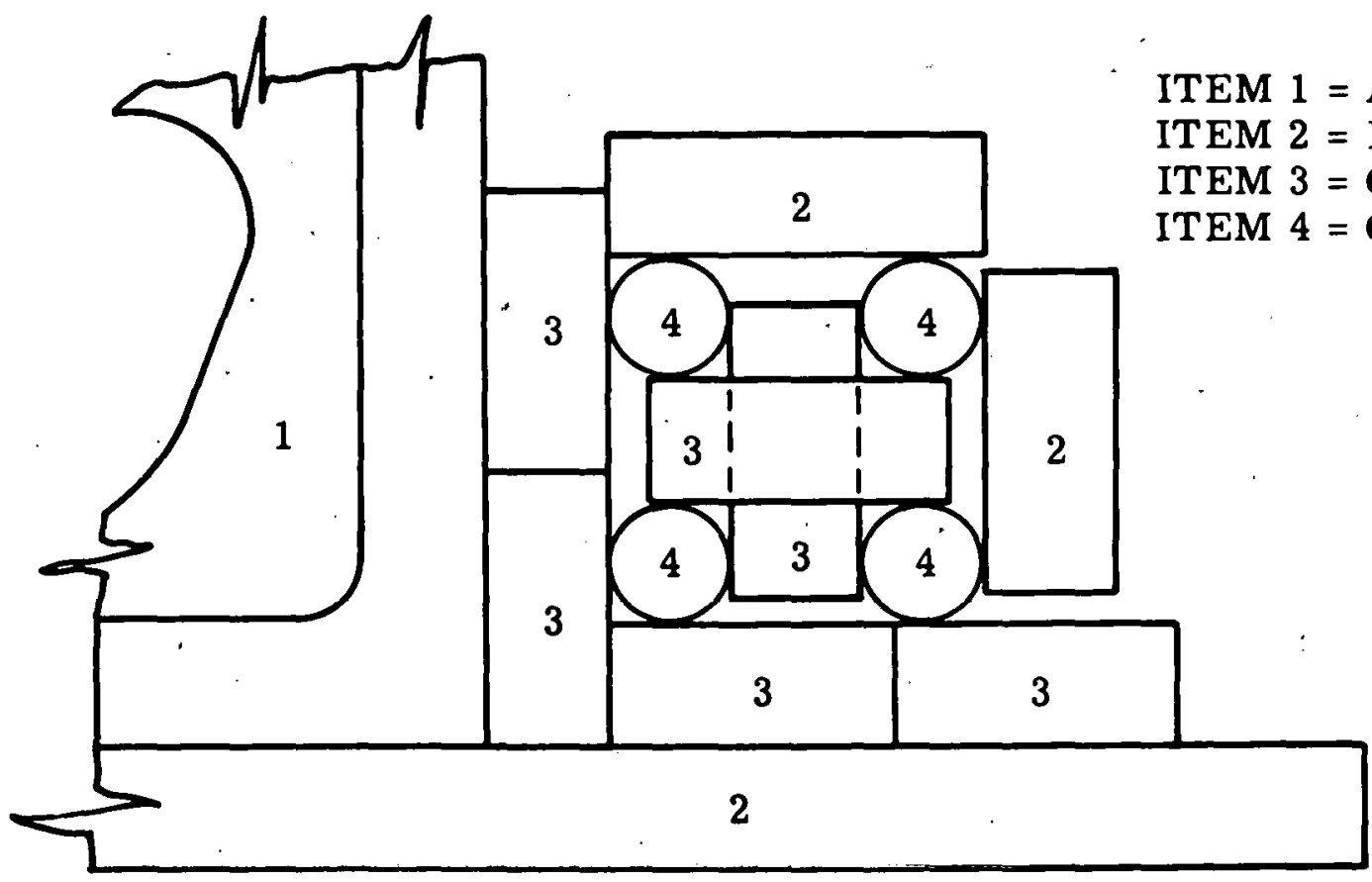

Figure 16 Gage Setup 